\title{
Along-Valley Structure of Daytime Thermally Driven Flows in the Wipp Valley
}

\author{
Magdalena RuCKeR* \\ Department of Earth and Ocean Sciences, The University of British Columbia, Vancouver, British Columbia, Canada, and \\ NOAA/Earth System Research Laboratory, Boulder, Colorado \\ ROBERT M. BANTA \\ NOAA/Earth System Research Laboratory, Boulder, Colorado \\ DOUw G. STEYN \\ Department of Earth and Ocean Sciences, The University of British Columbia, Vancouver, British Columbia, Canada
}

(Manuscript received 4 October 2005, in final form 16 May 2007)

\begin{abstract}
High-resolution Doppler lidar observations obtained during the Mesoscale Alpine Program (MAP) 1999 field campaign are used to investigate the along-valley structure of daytime valley flows in the Wipp Valley, Austria. The observations show that under varying ambient conditions the valley flow increases in speed through a narrow section of the valley. Furthermore, the along-valley volume flux diverges along the valley segment under investigation, which suggests that the observed along-valley acceleration of the valley flow cannot be explained by the horizontal constriction of the valley sidewalls. It is hypothesized that the along-valley acceleration of the flow is caused by an intravalley change in the horizontal pressure gradient induced by differential heating rates of the valley atmosphere.
\end{abstract}

\section{Introduction}

Thermally driven valley wind systems are an important feature of the atmospheric environment in mountainous terrain. Prevalent under fair-weather conditions, they regularly influence flow characteristics in mountain valleys and hence play an important role in environmental issues related to transport and diffusion of atmospheric trace species, such as air quality, emergency response, and agricultural applications, as well as applications sensitive to wind behavior, such as fire weather and aviation. Valley winds have been studied for many years, giving us a basic understanding of the temporal evolution and thermodynamic mechanism driving valley winds. In conceptual terms, valley winds

\footnotetext{
* Current affiliation: Sea Breeze Power Corp., Vancouver, British Columbia, Canada
}

Corresponding author address: Dr. Douw Steyn, Department of Earth and Ocean Sciences, The University of British Columbia, 6339 Stores Road, Vancouver, BC V6T 1Z4, Canada.

E-mail: dsteyn@eos.ubc.ca form as a result of horizontal pressure gradients that develop because of temperature differences between a valley and the adjacent plain. Wagner (1932) first suggested that the diurnal temperature variation between valley and plain was due to the smaller volume of air in the valley that needed to be heated or cooled compared to that over the plain. This volume effect has been estimated using the topographic amplification factor (TAF; Whiteman 1990), which considers a valley's cross-sectional area, or the area-height distribution (Steinacker 1984), which also takes into account heating effects of tributaries and high-lying plateaus. McKee and O'Neal (1989) used TAF calculations to show that pressure gradients, which develop within a valley because of changes in the valley geometry, can also be important in the formation of valley winds. A limitation of these methods to quantify the volume effect is that they are purely geometrical measures of the valley topography and do not take into account flow dynamics.

Although the formation of valley wind systems is attributed to topography, little is known about the spatial structure of valley flows along the valley axis and how the intensity of the flow relates to the topography of the 
valley. In studying the along-valley flow structure, it is useful to examine the mass or volume budget of the valley atmosphere, which accounts for the effects of changing valley cross sections on the flow. Along-valley volume flux divergence has been observed for the nighttime case (Rao 1968; Whiteman and Dreiseitl 1984; Post and Neff 1986), whereby the increase in the along-valley volume flux is at least partially attributed to air draining into the valley from tributaries and from katabatic flows. For the daytime case, it is often assumed that the along-valley volume flux converges as air in a valley is gradually removed through tributary and slope flows (e.g., Freytag 1988). Along-valley volume flux convergence indeed has been observed for the daytime case in midsized tributaries or end valleys (Buettner and Thyer 1965; Hennemuth 1987; Prévôt et al. 1998; Henne et al. 2004). On the other hand, alongvalley volume flux divergence has been reported for daytime valley flows in the Inn Valley (Freytag 1987) and in the Kali Gandaki Valley (Egger et al. 2000).

In this contribution, we investigate the along-valley structure of daytime flows in the Wipp Valley, Austria, using high-resolution Doppler lidar observations. These measurements, which also show along-valley volume flux divergence, were obtained in fall 1999 as part of the Mesoscale Alpine Program (MAP) field campaign (Bougeault et al. 2001). Although the MAPWipp Valley field work focused on foehn and gap flow events, a sequence of fine weather days during 11-17 October 1999 provided an opportunity to study thermally driven flows while taking advantage of existing instrumentation.

The outline of the paper is as follows. Section 2 briefly describes the study area, the instrumentation used in the field study as well as synoptic conditions. In situ and Doppler lidar observations of flow in the Wipptal are presented in section 3, and the along-valley volume flux is analyzed in section 4 . In section 5 , the results of this study are discussed in context of similar findings in other valleys. Section 6 summarizes the findings of this study.

\section{Description of field study}

\section{a. Location, topography, and period of observations}

The Wipp Valley, a predominantly NNW-SSEoriented valley located in North Tyrol, Austria (Fig. 1), is a major tributary valley of the Inn Valley. It runs from the city of Innsbruck ( $575 \mathrm{~m} \mathrm{MSL}$ ) south to the Brenner Pass (1373 m MSL). The valley is roughly 35 $\mathrm{km}$ long and has an average slope angle along the valley axis of $1.3^{\circ}$. The Wipp Valley has several tributaries, the largest one being the Stubai Valley near the mouth of the Wipp Valley.

The valley segment under investigation lies roughly within a 6-km radius of the Doppler lidar site (see Fig. 1 ). At the northern terminus of the segment (near the entrance of the valley), the Wipp Valley is roughly $\mathrm{V}$ shaped and $6 \mathrm{~km}$ in width at $800 \mathrm{~m}$ AGL. Just south of the mouth of the Stubai Valley, the Wipp Valley narrows to less than $4 \mathrm{~km}$ in width at $800 \mathrm{~m} \mathrm{AGL}$ and remains this narrow for approximately $3 \mathrm{~km}$ before widening again near the southern end of the segment. Because of the complexity of the terrain (such as bends in the valley, discontinuous ridgelines due to tributaries, and high-lying alpine plateaus that are part of the surrounding mountains), it is difficult to objectively determine an effective ridge height. Near its entrance, the slopes on either side of the Wipp Valley provide a relief of roughly $1200 \mathrm{~m}$. Further south, the terrain defining the eastern side of the Wipp Valley reaches a height of approximately $2400 \mathrm{~m}$ MSL, whereas the western ridgeline that separates the Stubai Valley from the Wipp Valley gradually increases to a height of $1700 \mathrm{~m}$ MSL. The depth of the Wipp Valley in the narrow segment is approximately $800 \mathrm{~m}$. Surrounding mountain peaks reach heights between 2600 and $2800 \mathrm{~m}$ MSL.

Measurements were obtained on 11, 13, 14, 16, and 17 October 1999. In this study, we present observations from 11,16 , and 17 October. Although thermally driven valley flows were observed on all five days, the 13 and 14 October are excluded from the present study because of external influences on the valley flow system. On 13 October, a downslope windstorm descending east of Stafflach (S; Fig. 1) disrupted the development of the thermally driven valley wind system, whereas on 14 October the valley flow was strongly influenced by the upper-level flow through down-mixing of momentum.

\section{b. Instrumentation}

A comprehensive description of the instrumentation in the Wipp Valley study area during the MAP Special Observing Period (SOP) can be found in Mayr et al. (2004). This study focuses on observations obtained from the Doppler lidar system as well as a network of surface meteorological stations.

The TEACO2 (so called because of its transversely excited atmospheric pressure discharge laser configuration, with carbon dioxide laser technology) Doppler lidar of the National Oceanic and Atmospheric Administration (NOAA) Environmental Technology Laboratory was deployed in the Wipp Valley near the village of Gedeir at an elevation of $1065 \mathrm{~m}$ MSL. The lidar transmits pulses of infrared light, a fraction of which is 


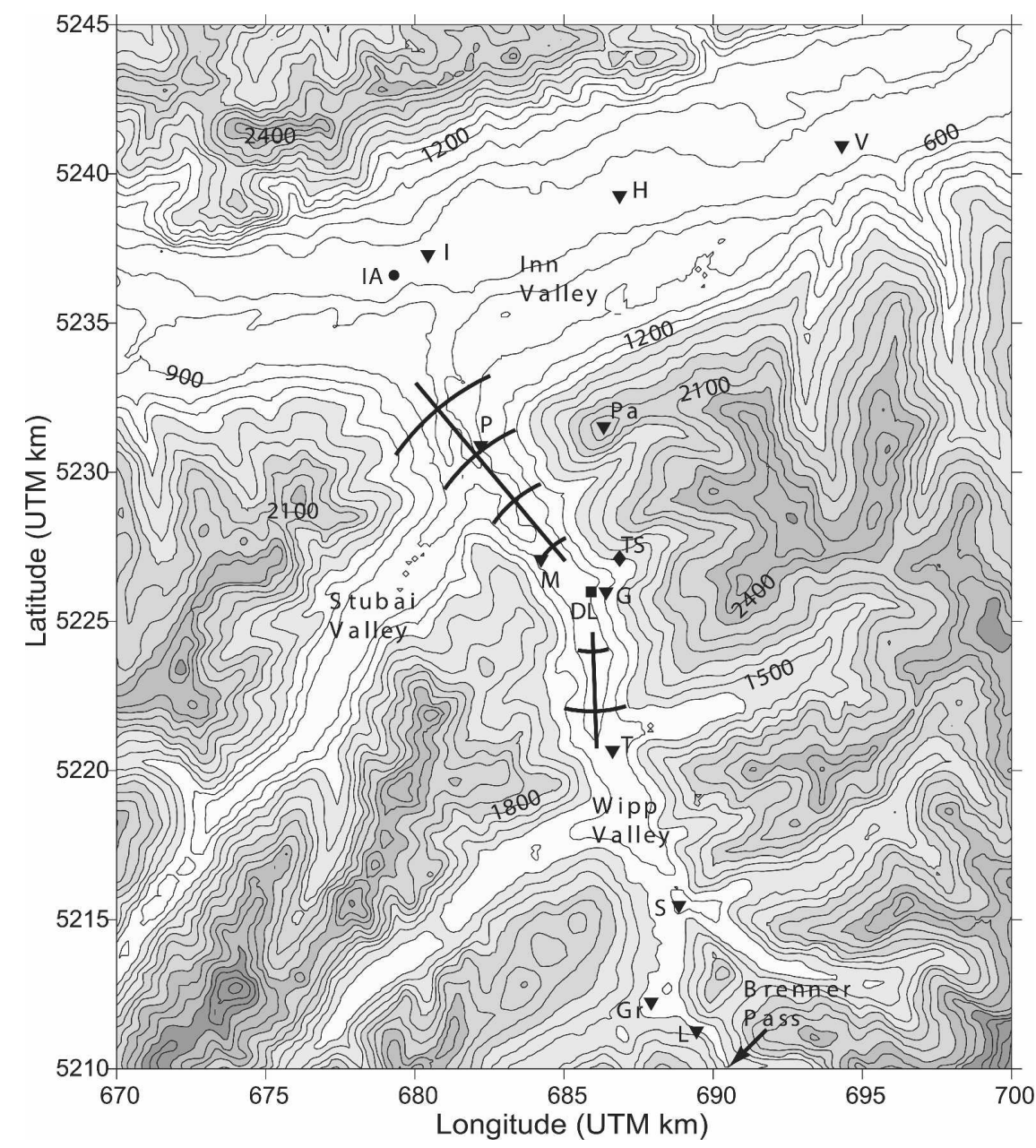

FIG. 1. Topographical map of the Wipp Valley area (contour interval $150 \mathrm{~m}$ ), showing measurement sites reported in this study. The Doppler lidar site is shown with a solid square (DL; $1065 \mathrm{~m} \mathrm{MSL),} \mathrm{while} \mathrm{the} \mathrm{surface} \mathrm{weather} \mathrm{stations} \mathrm{are} \mathrm{marked} \mathrm{with} \mathrm{solid} \mathrm{triangles.} \mathrm{Inn}$ Valley: V = Volders (601 m MSL), H = Hall (612 m MSL), I = Innsbruck City (609 m MSL); Wipp Valley: P = Patsch (960 m MSL), M = Matreiwald (985 m MSL), G = Gedeir (1132 m MSL), $\mathrm{T}=$ Tienzens (1168 $\mathrm{m}$ MSL), $\mathrm{S}=$ Stafflach (1149 $\mathrm{m} \mathrm{MSL}), \mathrm{Gr}=$ Gries (1326 m MSL), $\mathrm{L}=$ Luegg (1228 m MSL), Pa = Patscherkofel (2247 m MSL). The solid dot indicates the location of the Innsbruck Airport (IA; $579 \mathrm{~m} \mathrm{MSL}$ ) and the tethersonde site is marked with a solid diamond (TS; $1400 \mathrm{~m}$ MSL). The heavy line segments show the location of the Doppler lidar vertical-slice scans. Partial range rings are shown at $2-\mathrm{km}$ intervals from the lidar.

scattered back to the instrument by aerosol particles. The intensity of the backscattered energy is related to the concentration, size, and composition of the aerosols, and the Doppler-shifted frequency of the received signal reveals the radial wind velocity component along the direction of the lidar beam. More detailed information on the lidar can be found in Post and Cupp (1990). This Doppler lidar has been used successfully in a number of studies of flow over complex terrain, including sea breezes (Banta et al. 1993), nocturnal canyon and valley flows (Post and Neff 1986; Banta et al. 1995, 1999), wind-flow patterns in the Grand Canyon (Banta et al. 1999), and nocturnal low-level jets (Banta et al.
2004). Doppler lidar observations of gap/foehn flows during MAP are discussed in Flamant et al. (2002), Durran et al. (2003), Gohm et al. (2004), and Weissmann et al. (2004).

A pulse repetition frequency (PRF) of $10 \mathrm{~Hz}$ was used for this study. To reduce noise and improve reliability of the velocity estimates, five pulses were averaged for each velocity estimate, resulting in an effective PRF of $2 \mathrm{~Hz}$. The minimum range varied between 1.2 and $1.5 \mathrm{~km}$, and the maximum range was generally $7-8$ $\mathrm{km}$. The range gates were at $300-\mathrm{m}$ intervals, and the velocity accuracy was $0.6 \mathrm{~m} \mathrm{~s}^{-1}$ (Post and Cupp 1990). A number of different scans were conducted in rota- 
tion during this study. Vertical-slice scans along the center of the valley $\left(320^{\circ}\right.$ down valley of the lidar site and $178^{\circ}$ up valley of the lidar site) were used to resolve the vertical structure of the valley flow along the valley axis, whereas conical scans at various elevation angles were used to provide information on the horizontal flow structure. All scans were postprocessed to flag and remove terrain-contaminated range gates as well as range gates with weak signal-to-noise ratios. Vertical cross sections presented for 16 and 17 October were obtained by averaging two consecutive vertical-slice scans, taken over a 6-minute period, and horizontally projecting the radial velocity components to remove the effect of changing elevation angles. Given an average valley floor inclination of $1.3^{\circ}$, the horizontal projection differs from the terrain-following projection by $0.03 \%$. Vertical-slice scans were not available for 11 October 1999. To facilitate comparison to the other study days, pseudovertical cross sections were composed from conical scans, averaging radial velocities at each range gate over a $40^{\circ}$ sector centered on the $178^{\circ}$ and $320^{\circ}$ azimuths. (Note that for the first two pseudovertical cross sections shown in Fig. 4 below, the color coding does not reflect the true flow direction. This problem is an artifact of the graphing package and is caused by a combination of weak wind speeds and sparse data coverage. Arrows were therefore added to the images to indicate the correct flow directions as determined from the original conical scans.) The sign convention for velocities shown in the vertical cross sections is positive (negative) for flow in the up-valley (down-valley) direction, whereas in the conical plots, positive (negative) velocities denote flow toward (away from) the lidar.

In interpreting Doppler lidar radial velocity components in the context of three-dimensional flow fields, a priori assumptions generally have to be made about the flow. For the vertical cross sections shown in this study, we impose a two-dimensional view; that is, we assume that the flow within the valley sidewalls follows the direction of the valley axis. Since the azimuth angles of the vertical-slice scans are similar to the along-valley direction of the Wipp Valley (see Fig. 1), the radial velocity components in those scans do closely approximate the along-valley wind components. Several studies in other valleys (e.g., Hennemuth and Schmidt 1985; Weigel and Rotach 2004) have shown that circulations exist in the cross-valley direction and that the valley flow is not necessarily a two-dimensional flow phenomenon. These types of circulations, which are generally weak, are not taken into account in this study as it is not possible to identify cross-valley flow components using solely radial velocity measurements. However, the ex- clusion of cross-valley circulations does not affect the results presented here. For winds above the valley sidewalls, conical scans were analyzed to determine wind speed and direction of the flow aloft.

During the MAP-SOP, 35 surface weather stations were positioned throughout the study area. For this study, a subset of 11 stations located near the valley bottoms of the Inn Valley and Wipp Valley (see Fig. 1) was used to examine the diurnal behavior of the nearsurface winds in the valley. Data from all of these stations were available as 10 -min averages, with the exception of Gedeir and Gries, which were available as 1-h averages. In addition to these surface stations, mountain stations on the peaks of Patscherkofel (2247 m MSL) and Zugspitze (2960 m MSL; located approximately $35 \mathrm{~km}$ WNW from Innsbruck) were used to interpret ambient conditions. Synoptic network balloon soundings were launched from Innsbruck Airport at 0000 UTC for all days, with two additional soundings at 1200 and 1800 UTC on 17 October. Finally, tethersonde soundings obtained approximately $1.5 \mathrm{~km}$ from the lidar site on the slopes of a small tributary valley were available for 11 and 17 October.

All observations are presented using coordinated universal time (UTC). Solar noon as well as 1200 CET (central European time) corresponds to 1100 UTC. Theoretical times of sunrise and sunset are 0530 and 1630 UTC, respectively. These times do not account for the elevated horizon due to mountains or local shading effects. Near Gedeir, the valley bottom was sunlit at roughly 0745 UTC and shaded by 1430 UTC.

\section{Synoptic and local conditions}

Fair-weather conditions generally prevailed over the Wipp Valley area during the study period. An upperlevel ridge was located over central Europe on 11 October (Fig. 2a), with synoptic flow over the study region predominantly from the WNW. By 13 October, the upper-level ridge had amplified, forming a classic blocking omega ridge. During its life cycle (until 18 October), the omega ridge weakened somewhat, but generally remained over central Europe. During the latter half of the study period (Fig. 2b), the western Alpine region remained under weak gradients, whereas the eastern part was under the weak influence of a low situated to the east of the blocking ridge, producing northwesterly flows aloft.

Local ambient wind and cloud conditions for 11, 16, and 17 October are summarized in Table 1. On 11 October, the westerly winds observed at Innsbruck Airport and on top of the Zugspitze were in agreement with the general zonal synoptic flow of that day. Lidar 
a)

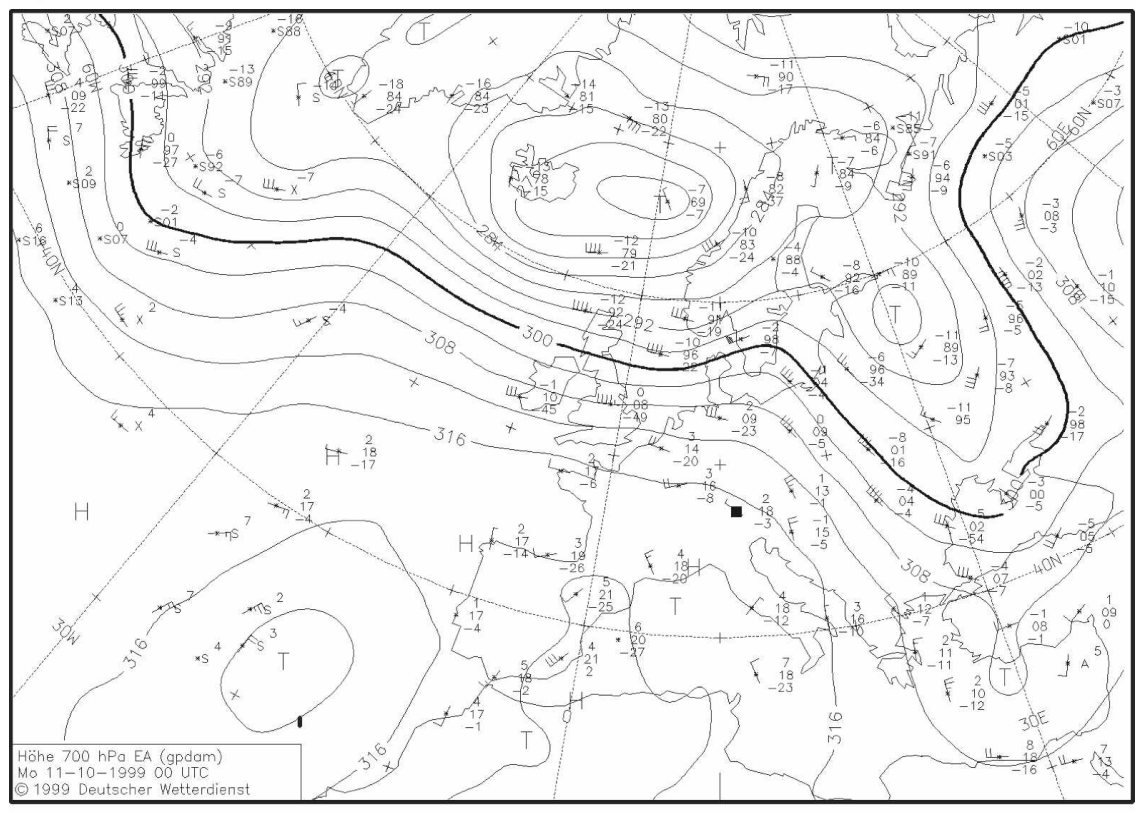

b)

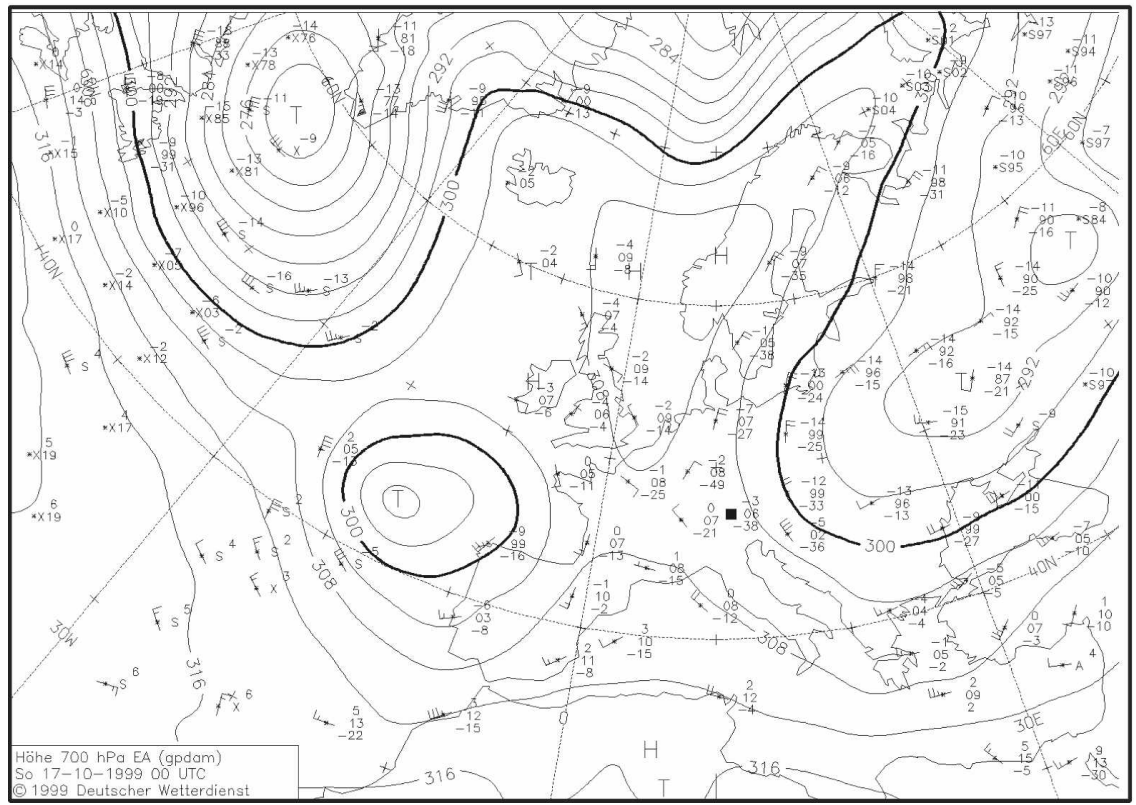

FIG. 2. Geopotential heights and winds at $700 \mathrm{mb}$ over central Europe at 0000 UTC for (a) 11 Oct and (b) 17 Oct. The solid square marks the location of Innsbruck.

observations, however, showed a weak $\left(4 \mathrm{~m} \mathrm{~s}^{-1}\right)$ southerly flow layer above 2200-2500 m MSL (also see Fig. 4, described below), which persisted throughout the day. The lower portion of this flow layer was also captured by tethersonde soundings. An early morning conical scan captured another flow reversal at approximately $3100 \mathrm{~m}$ MSL (not shown), suggesting that in the morning hours the southerly flow layer was roughly $600 \mathrm{~m}$ deep. Although it is not possible to determine the exact nature of the southerly flow, we surmise that the flow was caused by the north-south geostrophic pressure gradient, a process called pressure-driven channeling by Whiteman and Doran (1993). The separation of the valley wind system and the westerly synoptic flow by the southerly flow layer indicates that the synoptic flow had little or no influence on the thermally forced valley 
TABLE 1. Summary of local ambient conditions during the study period. Wind conditions at Innsbruck Airport are based on 0000 UTC (11 and 16 Oct) and 1200 UTC (17 Oct) radiosonde soundings, while wind conditions at Zugspitze, Patscherkofel, and Gedeir summarize daytime conditions. Conditions at Gedeir are based on vertical wind profiles derived from Doppler lidar conical scans. On 16 Oct, wind direction at Zugspitze was not available.

\begin{tabular}{|c|c|c|c|c|c|}
\hline Day & $\begin{array}{l}\text { Innsbruck Airport } \\
(2800-3000 \mathrm{~m} \text { MSL) }\end{array}$ & $\begin{array}{c}\text { Zugspitze } \\
(2962 \mathrm{~m} \text { MSL) }\end{array}$ & $\begin{array}{l}\text { Patscherkofel } \\
(2247 \text { m MSL) }\end{array}$ & $\begin{array}{c}\text { Gedeir } \\
(2400-2800 \mathrm{~m} \text { MSL) }\end{array}$ & Cloud/fog cover \\
\hline 11 Oct & $4 \mathrm{~m} \mathrm{~s}^{-1} \mathrm{WNW}$ & $8 \mathrm{~m} \mathrm{~s}^{-1} \mathrm{~W}$ & Light and variable & $4 \mathrm{~m} \mathrm{~s}^{-1} \mathrm{~S}$ & $\begin{array}{l}\text { Clear in morning; afternoon } \\
\text { convective clouds }\end{array}$ \\
\hline 16 Oct & $2 \mathrm{~m} \mathrm{~s}^{-1} \mathrm{~N}$ & $3 \mathrm{~m} \mathrm{~s}^{-1}$ & $1-2 \mathrm{~m} \mathrm{~s}^{-1} \mathrm{NW}$ & $2-4 \mathrm{~m} \mathrm{~s}^{-1} \mathrm{NW}-\mathrm{N}$ & $\begin{array}{l}\text { Morning valley fog; afternoon } \\
\text { convective clouds }\end{array}$ \\
\hline 17 Oct & $6 \mathrm{~m} \mathrm{~s}^{-1} \mathrm{WNW}$ & $3-6 \mathrm{~m} \mathrm{~s}^{-1} \mathrm{~W}-\mathrm{NW}$ & $3 \mathrm{~m} \mathrm{~s}^{-1} \mathrm{NW}$ & $8 \mathrm{~m} \mathrm{~s}^{-1} \mathrm{WNW}$ & $\begin{array}{l}\text { Morning valley fog; afternoon } \\
\text { convective clouds }\end{array}$ \\
\hline
\end{tabular}

flow system on this day. For both 16 and 17 October, the WNW-N flows above the ridgetops of the Inn Valley and Wipp Valley corresponded with the general synoptic conditions. On 16 October, the synoptic influence on the valley flow system was minimal because of very light ambient winds. The ambient flow on 17 October was stronger, but as will be discussed in the following section, the valley flow layer was likely decoupled from the ambient flow through an inversion layer. Although the ambient flow on 17 October was stronger than on 11 and 16 October, the observed valley wind speeds in the Wipp Valley were only slightly larger on 17 October than on the other two days. The similar valley wind speeds suggest that, for the days presented in this paper, the enhancement (weakening) of the valley flow in the Wipp Valley due to ambient winds in the same (opposite) direction was minimal. This is in contrast to results obtained by Weigel and Rotach (2004) where considerably higher valley wind speeds were found in the Riviera Valley on days when the ambient flow was in the up-valley direction.

\section{Observations}

\section{a. Surface observations}

The primary purpose of the continuous surface observations presented in this section is to affirm the thermal nature of the flows observed during the study period, thus providing an important context for the interpretation of the lidar observations. An underlying assumption for this analysis is that the surface winds are part of the valley wind system; that is, they are driven by the same thermal forcing that affects the entire valley atmosphere. While this assumption is reasonable for observations in the Inn Valley where the valley floor is almost horizontal, it may not be entirely appropriate for the Wipp Valley, which has a sloped valley bottom. In the latter case, the perceived up-valley winds at the surface may be described more accurately as slope flows along the valley axis [also called up-floor winds, e.g., Whiteman (1990)]. With the available observations, however, it is not possible to determine unequivocally to what extent the surface flows are due to the sloping valley bottom.

To determine if the observed flow was primarily thermally driven, the valley wind criteria of Dreiseitl et al. (1980), which essentially test for the twice-daily reversal of near-surface winds, were applied to all surface stations. The results, listed in Table 2, show that the valley wind criteria were satisfied on all three study days for the majority of stations. Failure of the valley wind criteria at Stafflach (S), Hall (H), and Volders (V) on 16 and 17 October was primarily due to the lack of organized nighttime down-valley flows, which meant that no wind reversal occurred during the morning hours. However, a marked increase in up-valley wind speeds during the daytime followed by calm winds in the evening was generally observed at these three stations. It is assumed that valley fog, which was present in the area on the mornings of these two days, hindered the development of the nocturnal portion of the valley wind circulation near the surface. This is also evident in the sea level pressure readings (not shown) at Innsbruck and Kufstein (located in the Inn Valley, approximately $70 \mathrm{~km}$ down valley from Innsbruck) which show for both 16 and 17 October a well-developed pressure gradient during daytime, but not at nighttime (Rucker 2003).

Figure 3 shows the daytime evolution of surface wind speeds at Tienzens, located $5 \mathrm{~km}$ up the valley from the

TABLE 2. Dreiseitl's valley wind criteria applied to surface weather stations shown in Fig. 1. Failure of the criteria is indicated by "N," and success by "Y." Dashes indicate missing data.

\begin{tabular}{|c|c|c|c|c|c|c|c|c|c|c|}
\hline \multirow[b]{2}{*}{ Day } & \multicolumn{7}{|c|}{ Wipp Valley } & \multicolumn{3}{|c|}{ Inn Valley } \\
\hline & $\mathrm{L}$ & $\mathrm{Gr}$ & $\mathrm{S}$ & $\mathrm{T}$ & $\mathrm{G}$ & $\mathrm{M}$ & $\mathrm{P}$ & I & $\mathrm{H}$ & $\mathrm{V}$ \\
\hline 11 Oct & $\mathrm{Y}$ & $\mathrm{Y}$ & $\mathrm{Y}$ & $\mathrm{Y}$ & $\mathrm{Y}$ & $\mathrm{Y}$ & - & - & $\mathrm{Y}$ & $\mathrm{Y}$ \\
\hline 16 Oct & $\mathrm{Y}$ & $\mathrm{Y}$ & $\mathrm{N}$ & $\mathrm{Y}$ & $\mathrm{Y}$ & $\mathrm{Y}$ & - & - & $\mathrm{Y}$ & $\mathrm{N}$ \\
\hline 17 Oct & $\mathrm{Y}$ & $\mathrm{Y}$ & $\mathrm{N}$ & $\mathrm{Y}$ & $\mathrm{Y}$ & $\mathrm{Y}$ & $\mathrm{Y}$ & $\mathrm{Y}$ & $\mathrm{N}$ & $\mathrm{N}$ \\
\hline
\end{tabular}


11 October

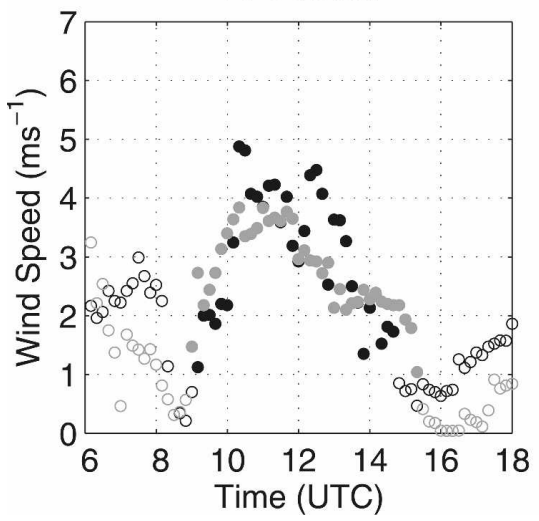

16 October

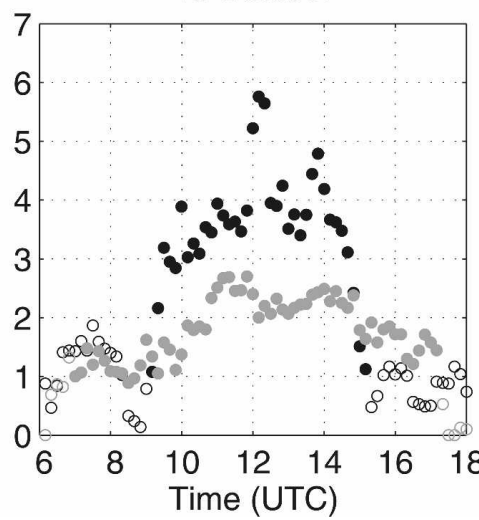

17 October

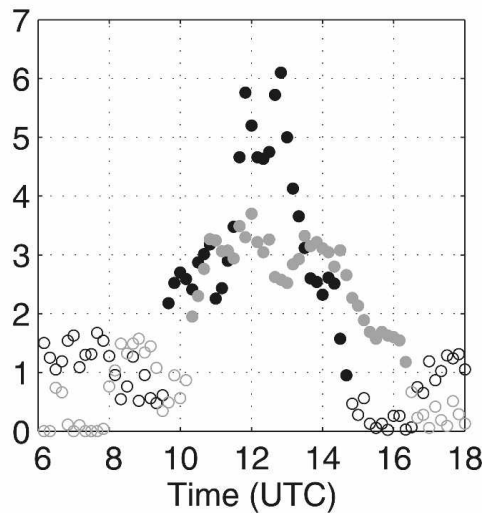

FIG. 3. Ten-minute average wind speeds on 11, 16, and 17 Oct 1999 for surface stations at Tienzens (T) south of the lidar site (black circles) and Matreiwald (M) north of the lidar site (gray circles). Periods with up-valley flow are shown by filled circles.

Doppler lidar site, and Matreiwald, located $2 \mathrm{~km}$ down the valley from the lidar site for all three study days. Although care has to be taken when comparing surface measurements due to possible influences of local topography, the surface winds at Tienzens are consistently stronger than those at Matreiwald. As will be shown in the following section, the increase in wind speed with distance in the up-valley direction is also evident in the Doppler lidar observations.

Based on the surface observations as well as synoptic effects discussed in the previous section, we conclude that the valley flows in the Wipp Valley were primarily thermally driven on the study days. In the following sections, Doppler lidar observations are used to investigate the spatial characteristics of the valley flow.

\section{b. Doppler lidar measurements along the Wipp Valley}

\section{1) LIGHT, SOUTHERLY EXTERNAL FLOW} (11 OCTOBER 1999)

Figure 4 shows the temporal evolution of the alongvalley flow structure on 11 October. During the previous night, the 0000 UTC sounding at Innsbruck Airport near the entrance of the Wipp Valley (not shown) showed a layer of southerly flow between 1400 and $2400 \mathrm{~m}$ MSL, overlying the nocturnal, down-valley flow, which in the Inn Valley was westerly. The top of this outflow layer from the Wipp Valley thus nearly coincided with the height of the ridge line (approximately $2400 \mathrm{~m}$ MSL) surrounding the Wipp Valley. As the up-valley wind layer (shown in yellow-magenta colors) developed through the morning, it was clearly distinguishable from the southerly flow aloft (blue-purple colors) which remained relatively weak throughout the day.
The onset of the up-valley flow at the surface occurred at roughly 0900 UTC. Lidar measurements at the same time captured a complex flow structure whereby a layer of southerly flow was sandwiched between layers of flow directed up valley. The elevated layer of southerly flow below $2200 \mathrm{~m}$ in the first two lidar images was most likely a remnant of the nocturnal, down-valley flow in the Wipp Valley. Similar flow features during the morning transition period have been observed in other valleys (e.g., Brehm and Freytag 1982; Whiteman 1982) whereby the elevated downvalley flow is associated with remnants of the nocturnal inversion.

By 1015 UTC, the up-valley flow layer had intensified and extended well above the lower ridgeline (dashed line) to the west of the Wipp Valley. The layer of southerly flow was almost completely eroded, although remnants of it were still visible north of the lidar site. By 1100 UTC, the up-valley flow was fully developed and extended almost $1400 \mathrm{~m}$ above the valley floor, or roughly to the height of the immediate terrain to the east of the Wipp Valley (solid terrain outline). Although the spatial coverage between up-valley and down-valley pointing lidar scans differed, the observations strongly point to a gradual increase in wind speed with distance in the up-valley direction. At 1230 UTC, for example, maximum wind speeds of $6-7 \mathrm{~m} \mathrm{~s}^{-1}$ were observed at about $250 \mathrm{~m}$ AGL north of the lidar site, whereas wind speeds of $8 \mathrm{~m} \mathrm{~s}^{-1}$ were observed $500 \mathrm{~m}$ above the valley floor south of the lidar site. Assuming a Prandtl-type profile for which the flow maximum occurs relatively close to the surface (e.g., Atkinson 1981), it is possible that wind speeds closer to the valley bottom exceeded $10 \mathrm{~m} \mathrm{~s}^{-1}$ south of the lidar site. At 1300 UTC, flow north of the lidar site had weakened somewhat but remained at the same intensity south of the 

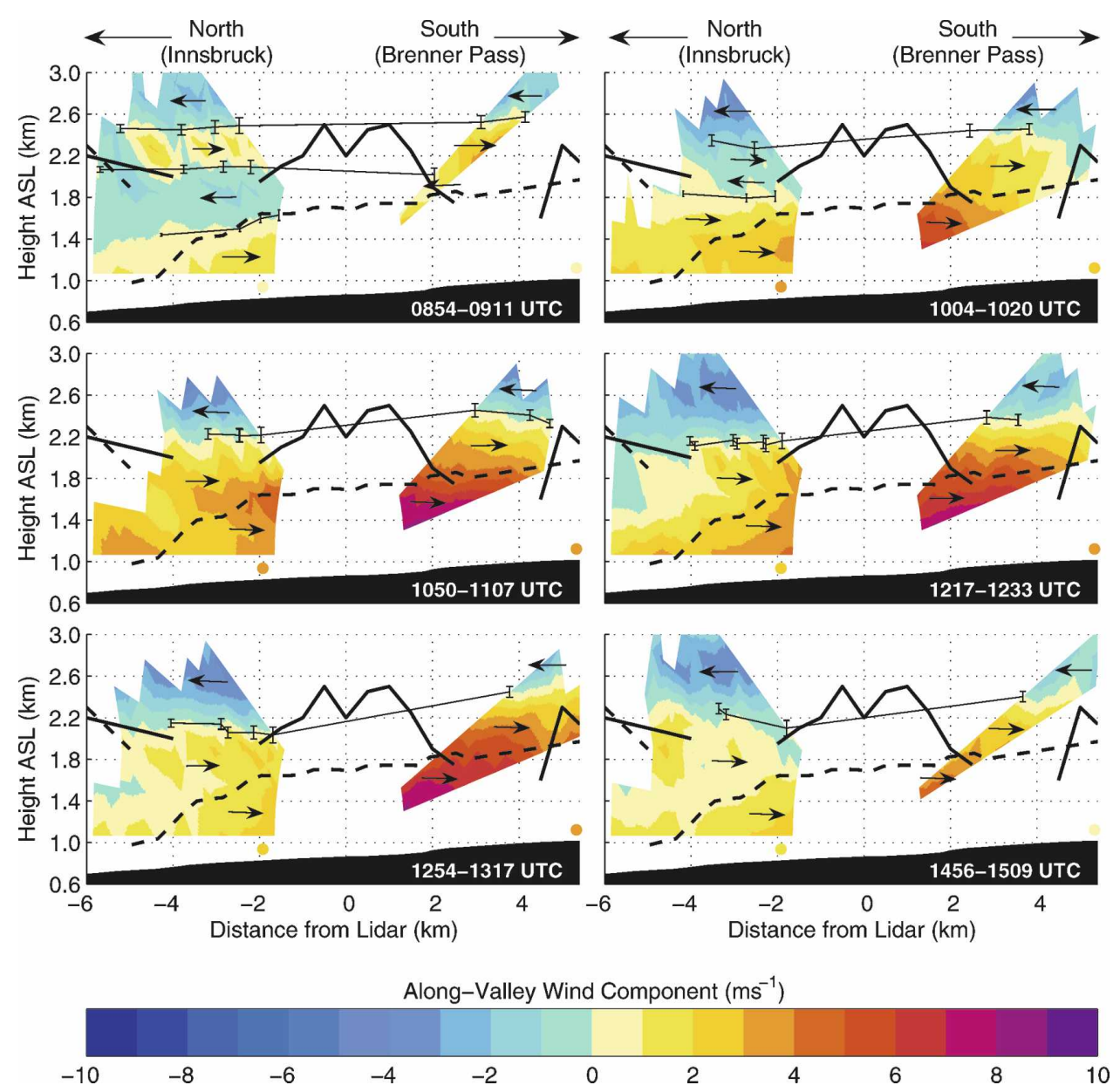

FIG. 4. Vertical cross sections along the valley centerline showing horizontally projected radial velocities for 11 Oct 1999. Data north of the lidar site are based on partial conical scans covering elevation angles $0^{\circ}$ to $30^{\circ}$ (in increments of $5^{\circ}$ ), while data south of the lidar site are based on conical scans with elevation angles ranging from $10^{\circ}$ to $25^{\circ}$ (in increments of $5^{\circ}$ ). Several faulty scans (particularly for the images at 0854,1254 , and 1456 UTC) were excluded from the analysis. Positive (negative) values indicate up-valley (down valley) flow. Arrows are superimposed to clarify wind direction. The thin lines mark the height of individual layers with opposing flow whereby the error bars indicate the vertical resolution (proportional to the cosine of the scan elevation angle). Near-surface along-valley wind speeds at Matreiwald and Tienzens are presented as dots at -2000 and $5000 \mathrm{~m}$ from the lidar site, respectively. The solid black area marks the valley floor. For reference, the eastern- and western-lying ridge lines are shown with solid and dashed lines, respectively. Up-valley direction is to the right.

lidar site. By 1500 UTC, the valley wind had weakened further but still attained speeds of $4-5 \mathrm{~m} \mathrm{~s}^{-1}$ at $500 \mathrm{~m}$ AGL south of the lidar site, whereas the flow at the same height north of the lidar site was no more than $1 \mathrm{~m} \mathrm{~s}^{-1}$. The valley wind near the surface ceased at 1500 and 1530 UTC for Tienzens and Matreiwald, respectively.

\section{2) Light, NORTHERLY EXTERNAL FLOW (16 OCTOBER 1999)}

Figure 5 shows vertical cross sections of the alongvalley winds for 16 October, when the ambient wind was weak and from a northwesterly direction. Upvalley flow at the surface was first observed at 0700 UTC for Matreiwald and 0900 UTC at Tienzens. By the time of the first vertical-slice scans at 1100 UTC, the up-valley flow layer was already well established, with a clear increase in wind speed occurring with up-valley distance. Similar to 11 October, a layer of southerly flow was visible north of the lidar site between 1600 and $2000 \mathrm{~m}$ MSL. A conical scan taken 10 min later shows that this layer existed across the entire valley cross section, but was slightly deeper toward the center of the valley than near the sidewalls. Although not visible in 

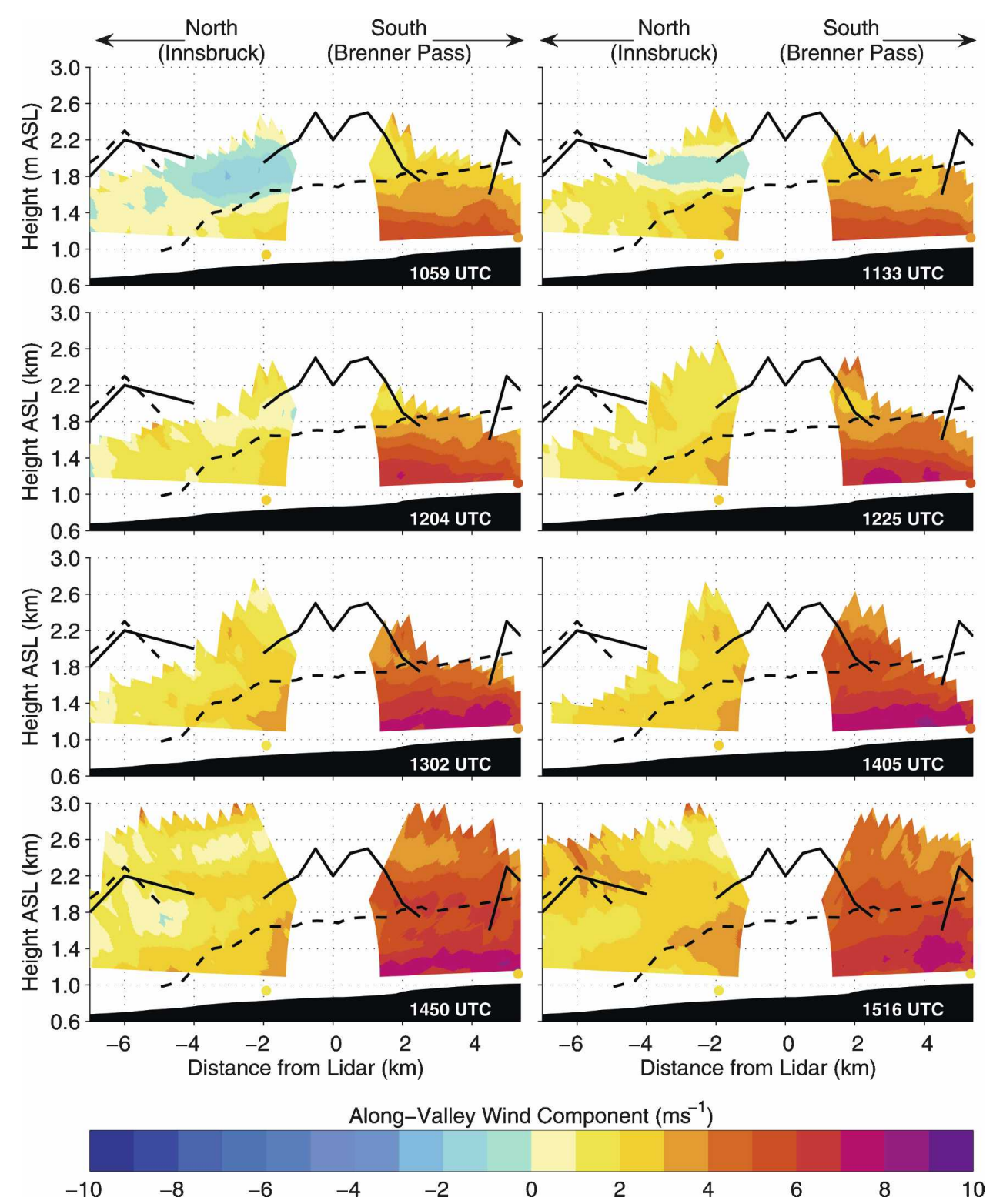

FIG. 5. As in Fig. 4, but for 16 Oct 1999. Cross sections are based on vertical-slice scans.

the vertical cross section, a small remnant of downvalley flow aloft could also be seen in conical scans south of the lidar site (the down-valley flow appeared toward the eastern sidewall and was therefore not visible in the vertical scans along the center of the valley). The existence of down-valley flow in the Wipp Valley also is supported by the 0000 UTC sounding at the Innsbruck Airport, which showed outflow from the Wipp Valley (i.e., down-valley flow) to a height of $2300 \mathrm{~m}$ MSL. By 1130 UTC, the down-valley flow in the upper valley segment had disappeared, while weak down-valley flow still persisted aloft in the lower valley segment. By 1200 UTC, the remnant of down-valley flow north of the lidar site had disappeared as well, and the up-valley flow now appeared fully developed. A slight increase in wind speed with distance in the upvalley direction could be seen within the vertical scans pointing to the north of the lidar, whereas a very noticeable increase in wind speed occurred between the down-valley and up-valley pointing segments of the scans. A clear vertical structure in the valley flow layer was not discernible north of the lidar site. South of the lidar site, vertical-slice scans until 1230 UTC showed a distinctly layered flow structure. After 1300 UTC, the vertical wind shear decreased somewhat as stronger wind speeds near the valley bottom were mixed to higher elevation levels. An analysis of vertical aerosol backscatter profiles along the Wipp Valley (Rucker 
2003) showed a well-defined jump in aerosol backscatter with height between 1800 and $2000 \mathrm{~m}$ MSL prior to 1225 UTC, but not in profiles taken at a later time. The correspondence of the observed "up mixing" of the wind field and dissipation of the layered flow structure with the disappearance of the step change in the vertical aerosol backscatter profiles suggests that a capping temperature inversion was eroded in the afternoon which allowed the valley flow to become coupled with the weak flow aloft, similar to the afternoon coupling found by Banta and Cotton (1981) and Banta (1984) in the Colorado Rocky Mountains.

Around 1500 UTC, the up-valley wind layer as defined by the minimum in wind speed (Whiteman and Dreiseitl 1984) extended roughly $1600 \mathrm{~m}$ above the valley floor. It is of interest to note that although the valley flow layer was still well established at 1500 UTC, the surface winds in the up-valley direction had greatly diminished. The up-valley flow at the surface ceased at 1700 and 1500 UTC for Matreiwald and Tienzens, respectively.

Figure 6 shows the vertical wind structure for constant range gates north and south of the lidar site. It should be noted that since the data were taken from constant range gates, the profiles are not truly vertical, but follow an arch. The maximal horizontal difference from the true vertical is $350 \mathrm{~m}$. In addition to a very pronounced increase in wind speed that occurred in the up-valley profile, a change in the shape of the vertical wind profile is also evident. Although the lidar scans in the down-valley direction did not cover the lowest 300 $\mathrm{m}$ of the flow, the wind profiles down valley from the lidar site nevertheless appear consistently flat or weakly curved. Up valley from the lidar, the flow maximum was more pronounced and occurred closer to the surface. A similar change in the vertical wind profile was also observed along a 18-km stretch of the Inn Valley during the Mesoscale Experiment in the Region Kufstein-Rosenheim (MERKUR; Reiter et al. 1984). The Doppler lidar measurements presented in this study, however, show that such change in the wind profile can take place over a distance of several kilometers. The reason for change in the shape of the vertical wind profile is not known. As a final point of interest, the wind speed north of the lidar site appeared almost stationary during the period that the Doppler lidar was operational, whereas south of the lidar site a more noticeable increase in wind speed occurred.

\section{3) Moderate, NORTHERly EXTERnAl FLOW} (17 OCTOBER 1999)

The vertical cross sections obtained on 17 October (Fig. 7) show a well-developed up-valley flow regime that is clearly separated from the upper-level flow by a wind speed minimum. The upper-level flow on this day was moderate and from the northwest. The wind speed minimum coincided with a strong inversion layer at roughly $1800 \mathrm{~m}$ MSL, which was evident in the 1200 UTC sounding at Innsbruck Airport and also in the afternoon tethersonde soundings near Gedeir. It therefore appears that the valley flow was decoupled from the upper-level flow by this inversion layer. The depth of valley flow, as defined by the wind minimum, was roughly $800 \mathrm{~m}$. As was the case for the other study days, the intensity of the valley flow increased across the minimum range of the lidar. In contrast to 16 October, however, the valley flow on 17 October continued to increase south of the lidar site, with the maximum wind speed occurring roughly $4 \mathrm{~km}$ downstream from the lidar. The increase in wind speed along the valley segment was not just limited to the valley proper, but extended to a height of $2600 \mathrm{~m}$ MSL. Above $2600 \mathrm{~m}$ MSL, velocity-azimuth display (VAD) analysis showed the wind speed to be constant and from the northwest. The apparent decrease in the along-valley (radial) wind component in the vertical cross sections at this height and above are due to the different azimuth angles with respect to the flow above ridgetops with which the upand down-valley scans were obtained.

Greater lidar range on this day allowed the vertical slices in Fig. 7 to be extended into the entrance region of the Wipp Valley ( -7 to $-10 \mathrm{~km}$ mark). In this region, the a priori assumption of along-valley flow is not applicable, and hence care has to be taken when interpreting the Doppler lidar data.

Under thermally driven conditions, it is generally assumed that air is drawn from the main valley into the tributary. Northerly flow, or flow toward the mouth of the Wipp Valley, was indeed observed during daytime at the Innsbruck surface station (see Fig. 1). The weak negative radial velocities obtained with the Doppler lidar, however, indicate that the direction of the flow between 1200 and $2000 \mathrm{~m} \mathrm{MSL}$ was $50^{\circ}$ or greater; that is, the flow at those elevations was oriented more along the ENE-WSW direction of the Inn Valley rather than the NNW-SSE direction of the Wipp Valley. Innsbruck Airport soundings at 1200 and 1800 UTC confirmed the presence of up-valley flows in the Inn Valley to heights of 1800 to $2000 \mathrm{~m}$ MSL. From the available observations, it is not possible to ascertain if the higher-level flow continued along the Inn Valley, or entered the Wipp Valley along the western half of the valley. Strong channeling of valley winds has been observed in the Riviera Valley (Weigel and Rotach 2004), but this has been primarily attributed to the curvature of the terrain near the mouth of the Riviera Valley. 

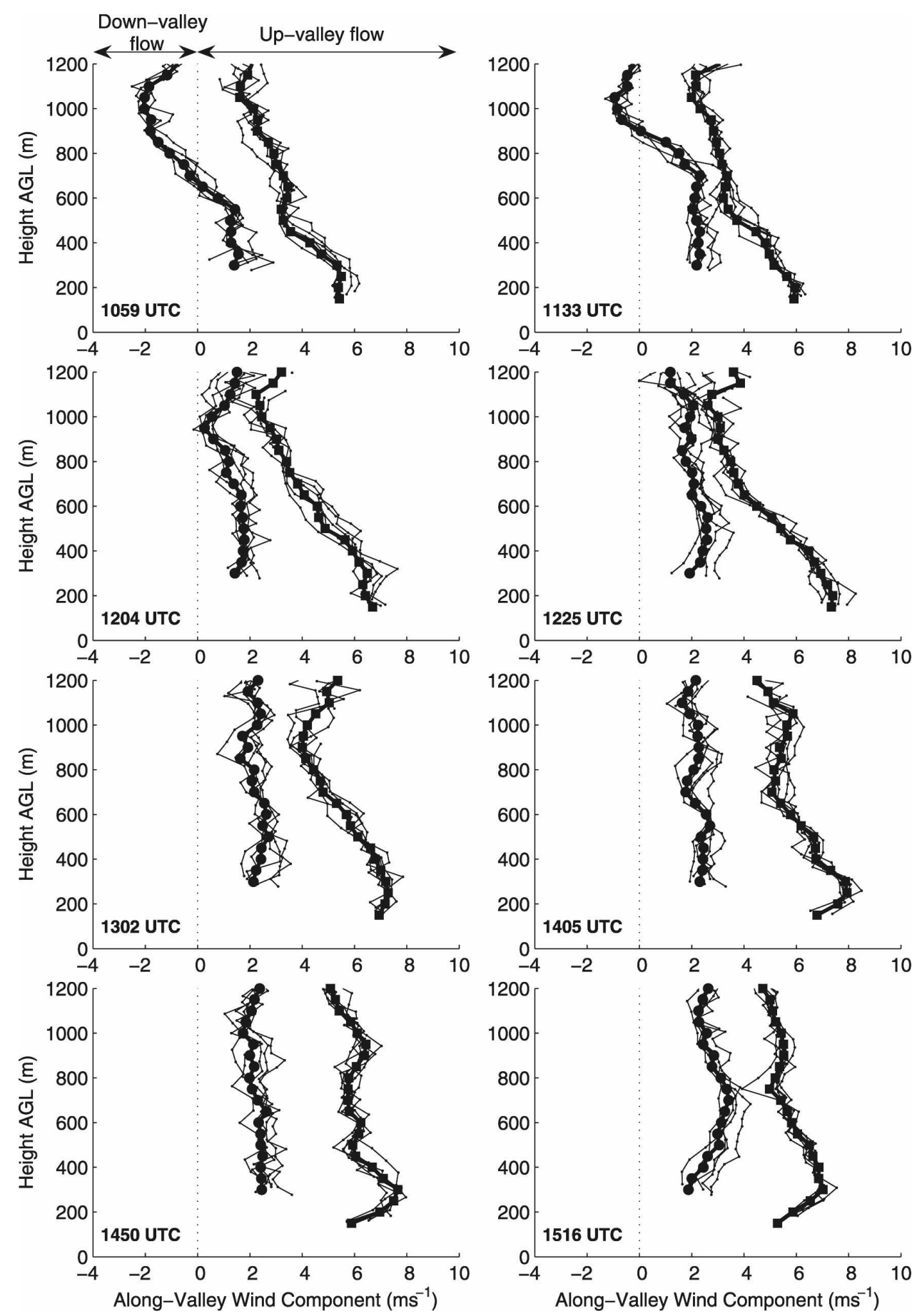

FIG. 6. Vertical profiles of the horizontal along-valley wind component for range gates 8-12 (2.25-3.45 $\mathrm{km}$ from lidar) north (solid circles) and south (solid squares) of the lidar site for 16 Oct 1999. Thin lines with dots show individual profiles, whereas heavy lines with solid circles-squares indicate averaged profiles.

The vertical wind profiles (Fig. 8) are similar to those observed on 16 October. Again, the wind profile north of the lidar appeared to have only slight curvature, whereas the wind profile south of the lidar showed a pronounced wind speed maximum approximately 200 $\mathrm{m}$ above valley bottom. The ratio of the height above ground of the wind speed maximum and the depth of the up-valley flow layer $(800 \mathrm{~m})$ for the wind profile 

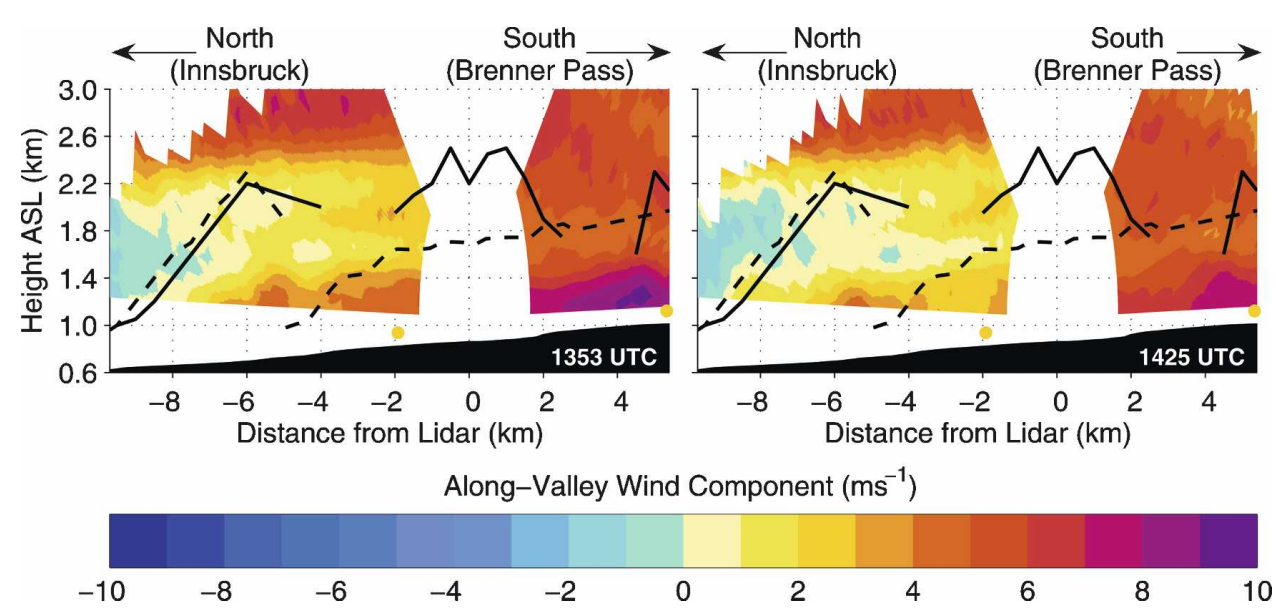

FIG. 7. As in Fig. 5, but for 17 Oct 1999.

south of the lidar is 0.25 . This ratio closely corresponds to that of a Prandtl-shaped profile (Atkinson 1981). It is not implied, however, that the mechanism proposed by Prandtl (1942) for simple slope flows is applicable to up-valley flows.

\section{c. Doppler lidar measurements across the Wipp Valley}

Although the primary orientation of the Wipp Valley is NNW-SSE, the valley exhibits several bends along its length. Research in other valleys with curvature, such as the Loisach Valley and the Riviera Valley, has shown that thermally driven valley flows can exhibit characteristics of curved channel flow (Reiter et al. 1983; Weigel and Rotach 2004). In this section, we examine the cross-valley flow structure from conical scans to see if similar banking of the valley flow occurred in the Wipp Valley.

Figure 9 shows the radial velocity for a series of lowlevel conical scans obtained north of the lidar site on 11
October. These scans, which can be considered as instantaneous snapshots of the flow field, show fluctuations in the cross-valley flow structure which may be associated with flow under convective conditions. Persistent asymmetries in the cross-valley structure, however, are not evident. The positive radial velocity components seen in Fig. 9 near the entrance region are consistent with up-valley flow branching off from the Inn Valley. The exact orientation of the flow in the entrance region, however, cannot be determined from the Doppler lidar scans.

Radial velocities for conical scans on 11,16 , and 17 October are shown in Fig. 10 for a slightly higher elevation angle. Although the valley orientation south of the lidar site changes from $165^{\circ}$ to $180^{\circ}$, no persistent banking of the valley flow toward the eastern sidewall is evident. Weak radial velocities south of the lidar site on the west side as well as negative radial velocities north of the lidar site on the east side occurred near the entrances of tributaries, and hence are interpreted as flow branching off into the tributaries. Measurements were
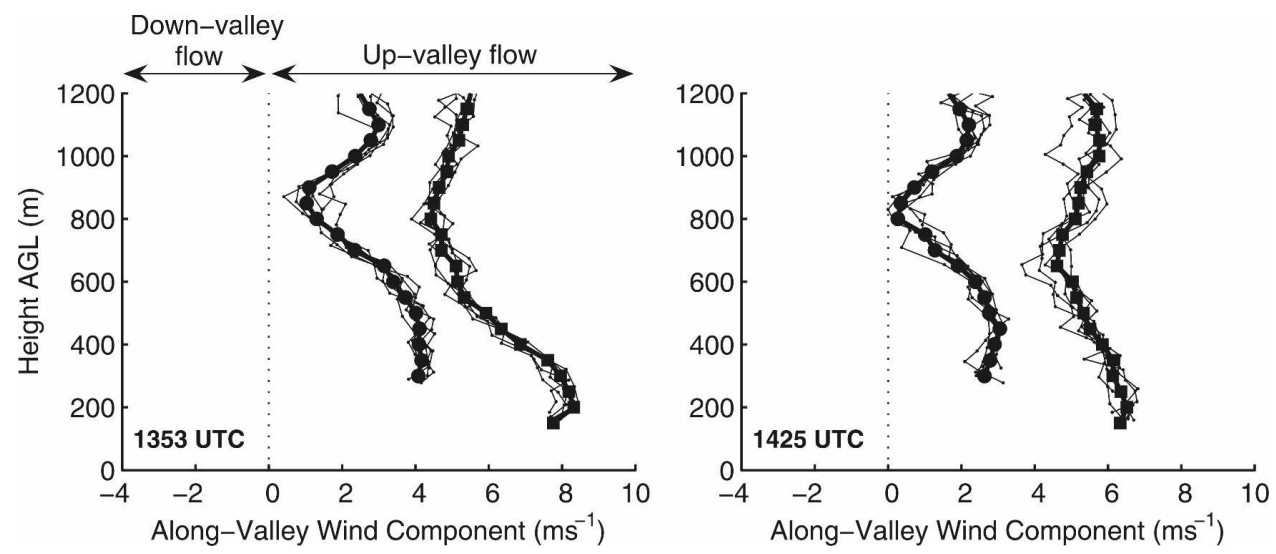

FIG. 8. As in Fig. 6, but for 17 Oct 1999. 
a)

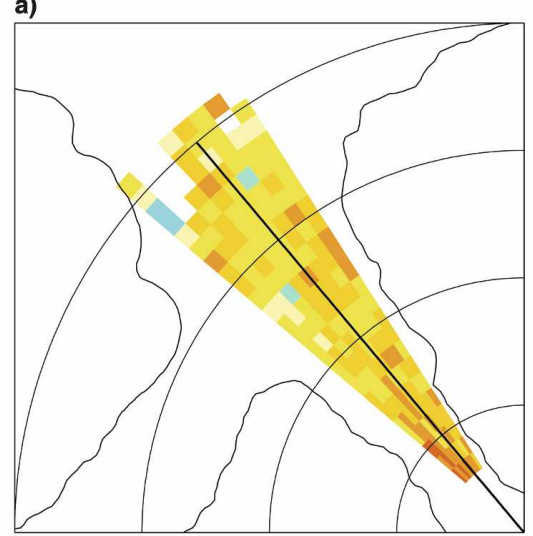

c)

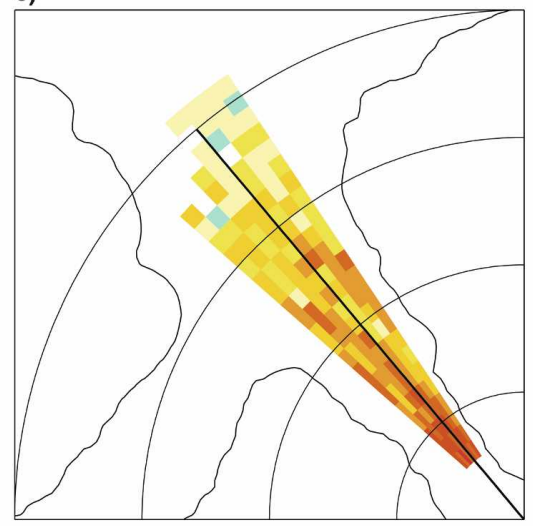

b)

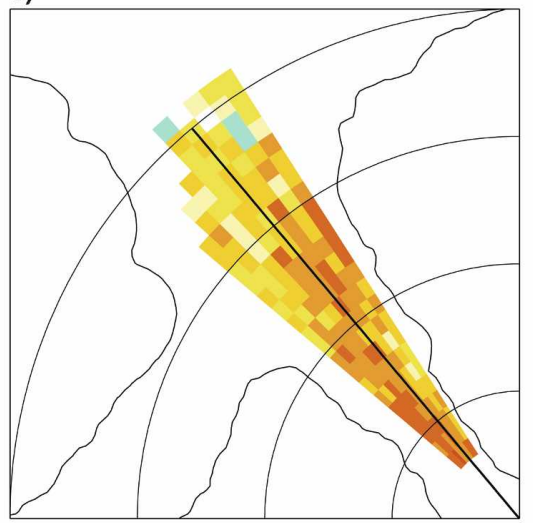

d)

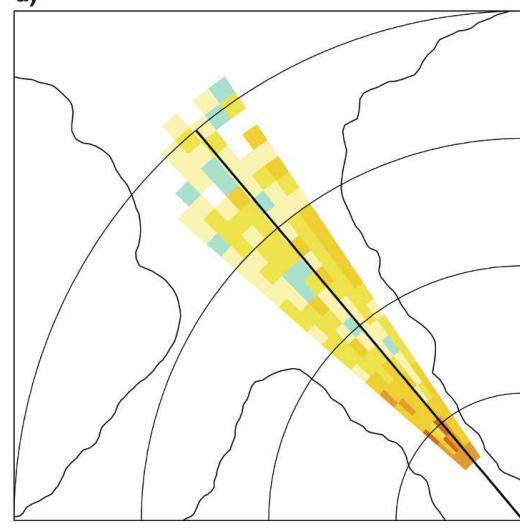

Radial Velocity $\left(\mathrm{ms}^{-1}\right)$

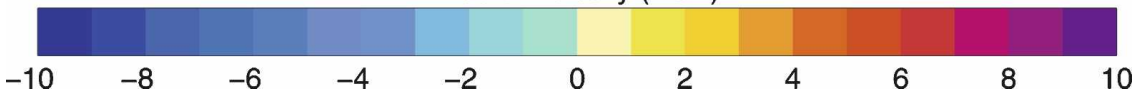

FIG. 9. Partial conical scans at $0^{\circ}$ elevation for 11 Oct at (a) 1015 UTC, (b) 1102 UTC, (c) 1217 UTC, and (d) 1254 UTC. The images show the radial velocity component, with positive values indicating flow toward the lidar and negative values denoting flow away from the lidar. Superimposed is the topographic contour line at the same height of the scan (1065 m MSL). The range rings mark the horizontal distance in 2000-m intervals from the lidar site, located at the lower right corner of each figure.

not available to confirm the presence of up-valley flows in those tributaries, but up-valley flows were clearly observed in the small tributary to the east of the lidar site, and hence it is assumed that up-valley flows were present in other tributaries as well. On 17 October, influence of the tributary extended farther into the Wipp Valley than on 11 and 16 October. It is postulated that the temperature inversion that was present on this day at $1800 \mathrm{~m}$ MSL may have limited the vertical movement of air, hence increasing the horizontal range from which air is drawn into the tributary. Alternatively, the temperature inversion may have intensified the valley flow circulation by confining the heat input to certain altitudes in the valley (Steinacker 1984).

The apparent lack of banking of the daytime up- valley flow in the Wipp Valley in comparison to observations made in the Loisach Valley or the Riviera Valley may be due to the smaller changes in direction. In the Wipp Valley, changes in the valley orientation are less than $20^{\circ}$ while in the Loisach Valley and Riviera Valley, the bends are closer to right angles.

\section{Along-valley volume flux calculations}

In the previous section, it was shown that under various ambient conditions the flow in the Wipp Valley increased in wind speed with up-valley distance. The main along-valley acceleration occurred in an area where the valley narrows considerably. In this section, we present calculations of the along-valley volume flux 
a)

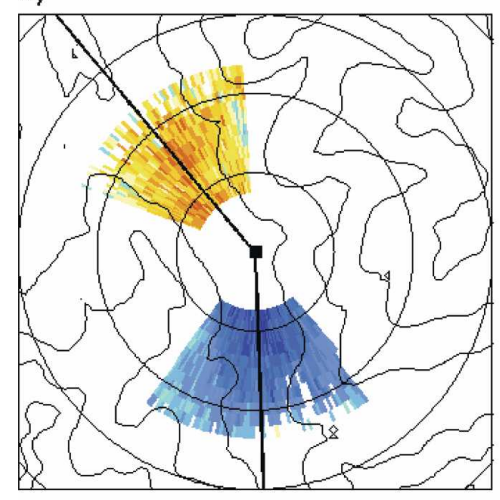

b)

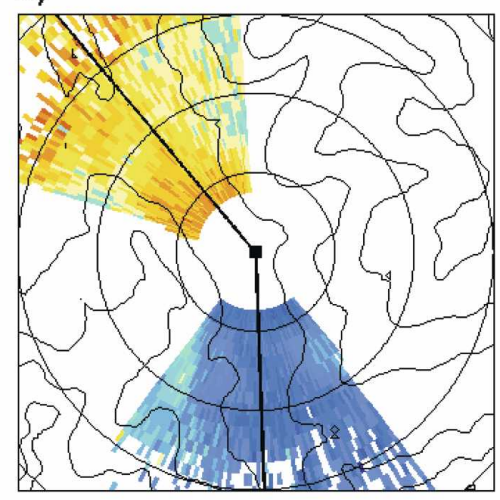

c)

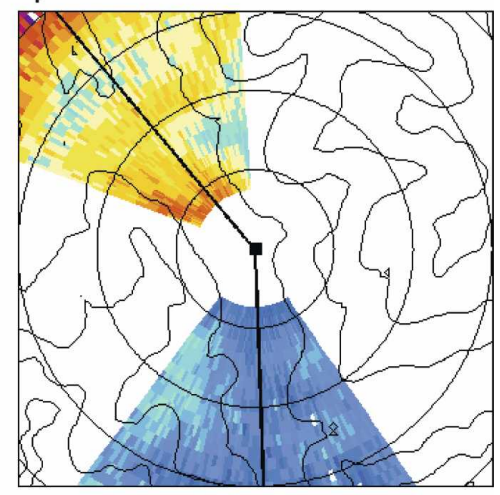

Radial Velocity $\left(\mathrm{ms}^{-1}\right)$

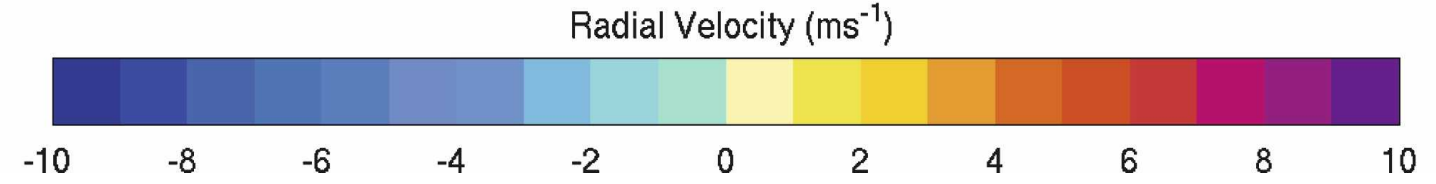

FIG. 10. Conical scans at $10^{\circ}$ elevation for (a) 11 Oct at 1050 UTC, (b) 16 Oct at 1453 UTC, and (c) 17 Oct at 1333 UTC. The images show the radial velocity component, with positive values indicating flow toward the lidar and negative values denoting flow away from the lidar. Superimposed are topographic contour lines in intervals of $400 \mathrm{~m}$, beginning at $800 \mathrm{~m}$ MSL. The range rings mark the horizontal distance in 2000-m intervals from the lidar site (shown with a solid square). The corresponding heights of the range rings are 1420,1770 , and $2120 \mathrm{~m}$ MSL. The straight lines mark the $178^{\circ}$ and $320^{\circ}$ azimuths.

along the Wipp Valley to examine how the increase in wind speed relates to the horizontal constriction of the valley sidewalls.

\section{a. Analysis}

In the following analysis, we assume the flow to be steady and incompressible. The incompressibility assumption allows the air density to be treated as a constant and mass fluxes to be expressed as volume fluxes. The steady-state volume flux budget for a valley segment is given by

$$
V_{x_{\text {out }}}-V_{x_{\text {in }}}+V_{\text {tributary }}+V_{\text {slope }}+V_{w}=0,
$$

where $V_{x_{\text {out }}}$ is the along-valley volume flux leaving the valley segment, $V_{x_{\mathrm{in}}}$ is the along-valley volume flux entering the valley segment, $V_{\text {tributary }}$ is the volume flux leaving through tributaries, $V_{\text {slope }}$ is the volume flux leaving via slope flows, and $V_{w}$ is the volume flux leaving the segment through the top (fluxes are positive for the direction of flow indicated in the definition of the fluxes). From Eq. (1), we can infer that for the daytime situation, mass leaving the valley segment through tributary and/or slope flows is balanced either through flow convergence along the valley axis $\left(V_{x_{\text {out }}}-V_{x_{\text {in }}}<0\right)$ or through subsidence $\left(V_{w}<0\right)$ at the top of the valley segment. However, if there is volume flux divergence along the valley axis $\left(V_{x_{\text {out }}}-V_{x_{\text {in }}}>0\right)$, then subsidence must occur to balance both the along-valley flow divergence and air leaving through slope and tributary flows. This analysis concerns itself primarily with the alongvalley volume flux, and the vertical motion implied by the along-valley volume flux divergence-convergence. The magnitudes of the tributary and slope flows are not known. However, these flows act in the same sense as along-valley flow divergence in that they remove airmass from the valley, and hence inclusion of these flows in the volume flux budget would not change the sign of the vertical motion, only the magnitude.

The along-valley volume flux was calculated for each range gate using the formula

$$
V_{x}(x)=\int_{0}^{h(x)} F u(x, z) W(x, z) d z
$$

where $V_{x}(x)$ denotes the total along-valley volume flux $\left(\mathrm{m}^{3} \mathrm{~s}^{-1}\right)$ as a function of along-valley distance $x(\mathrm{~m})$, $W(x, z)(\mathrm{m})$ is the width of the valley as a function of distance and height above ground level $z(\mathrm{~m}), u(x, z)$ $\left(\mathrm{m} \mathrm{s}^{-1}\right)$ is the lidar-measured, along-valley wind component as a function of distance and height, and $h(x)$ $(\mathrm{m})$ is the depth of the valley flow. The weighting factor $F$ represents the ratio of the mean cross-sectional, along-valley wind speed and the wind speed measured at the center of the valley. This weighting factor, which is very similar to the flux ratio used by King (1989), 
takes into account that the along-valley flow component varies across the valley. For this study, a value of 0.87 was estimated for the weighting factor $F$ using radial velocities from conical scans. Effects of tributary flows on cross-valley profiles were excluded. Vertical profiles of the horizontally projected radial velocities were smoothed using a Gaussian filter with a sigma of $50 \mathrm{~m}$. Since the lidar observations did not extend to the valley bottom, the wind profiles were extrapolated to the surface using a generalized Prandtl formulation (Rucker 2003). The volume flux based on the extrapolated portion of the flow is $1 \%-7 \%$ of the total volume flux south of the lidar site, and $6 \%-16 \%$ of the total volume flux north of the lidar site. Cross-sectional widths at each range gate were determined from a 100m-resolution digital terrain model of Tyrol. In areas where the valley width was ill defined because of tributaries, cross-sectional profiles were linearly interpolated to profiles on either side of the tributary. All volume flux calculations were based on a depth of $800 \mathrm{~m}$, since for this depth most of the flow was confined by sidewalls on either side of the valley. Hence, volume flux estimations for 17 October include the entire valley flow layer, whereas estimations for 11 and 16 October are based on only a portion of the valley flow.

To estimate uncertainties in the volume fluxes due to measurement errors or analysis assumptions, the calculations were also performed using values of 0.82 and 0.92 for the weighting factor $F$. In addition, straight line extrapolations were applied to wind profiles north of the lidar site to account for possible underestimations of the along-valley volume flux by using the Prandtl formulation. Another problem in the volume flux estimations arose for profiles south of the lidar site where the valley widens. From conical scans (e.g., Fig. 10) it appears that the up-valley flow may not entirely fill the widened valley segment. Hence, narrower cross-sectional profiles were estimated using radial velocity patterns from conical scans as guidance. Finally, volume fluxes north of the lidar site were also calculated assuming a 200-m deeper flow layer (Rucker 2003).

\section{b. Results}

Figure 11 shows the along-valley volume flux, volume flux density (which can be interpreted as the average wind speed of the whole valley flow layer), and cross-sectional area along a 7-km-long segment of the Wipp Valley for 17 October. North of the lidar site, the along-valley volume flux is roughly constant, and hence the slight increasing trend in the volume flux density may be attributed to the decrease in cross-sectional area north of the lidar site. A considerable increase in the along-valley volume flux as well as volume flux den- sity, however, occurs over a distance of roughly $3 \mathrm{~km}$, centered on the lidar site. Over this distance, the crosssectional area of the Wipp Valley is almost constant with only a slight increase toward the southern end. The fact that the along-valley volume flux diverges along this valley segment even though the cross-sectional area remains almost constant, indicates that the increase in wind speed cannot be explained by the horizontal constriction of the valley sidewalls. Farther south of the lidar site, the volume flux density continues to increase even though the cross-sectional area remains roughly constant, hence leading to an increase in the along-valley volume flux downstream of the constriction.

The mean vertical motion required to balance the along-valley volume flux divergence on 17 October was calculated by dividing the difference in volume flux between the outflow and inflow boundaries by the total area at the top of the valley segment. For a 2700-m-long valley segment centered on the lidar site, an average subsidence of $0.45 \mathrm{~m} \mathrm{~s}^{-1}$ is required to balance the along-valley volume flux divergence at 1353 and 1425 UTC. Taking into account uncertainties in the volume flux calculations, the range in subsidence is $0.17-0.51$ $\mathrm{m} \mathrm{s}^{-1}$ and $0.24-0.49 \mathrm{~m} \mathrm{~s}^{-1}$ for 1353 and 1425 UTC, respectively. It should be noted that in calculating the subsidence velocities, only flow in the along-valley direction was taken into account. In reality, slope and tributary flows also affect the volume budget in a valley segment. For the daytime case, both slope and tributary flows remove air from a valley segment. Hence, the subsidence velocities represent minimum values as they do not take into account additional flow divergence due to slope and tributary flows.

The subsidence rate estimated for this work is considerably larger than the subsidence rate determined by Freytag (1987) for the Inn Valley, where along-valley volume flux divergence was also observed. For a 37km-long section along the Inn Valley, Freytag (1987) calculated a subsidence velocity of $0.05 \mathrm{~m} \mathrm{~s}^{-1}$ required to balance the along-valley volume flux divergence. The large difference in the two estimations may be partly due to the different nature and scale of the measurements in the two valleys. For the Wipp Valley, the lidar observations capture very localized changes in the flow, whereas the calculations for the Inn Valley are based on soundings placed roughly $18 \mathrm{~km}$ apart, and hence may be considered as subsidence rates averaged over a much larger region.

A detailed volume flux analysis for the entire valley flow layer is not presented for 11 and 16 October, since on these two days the valley flow extended above the 

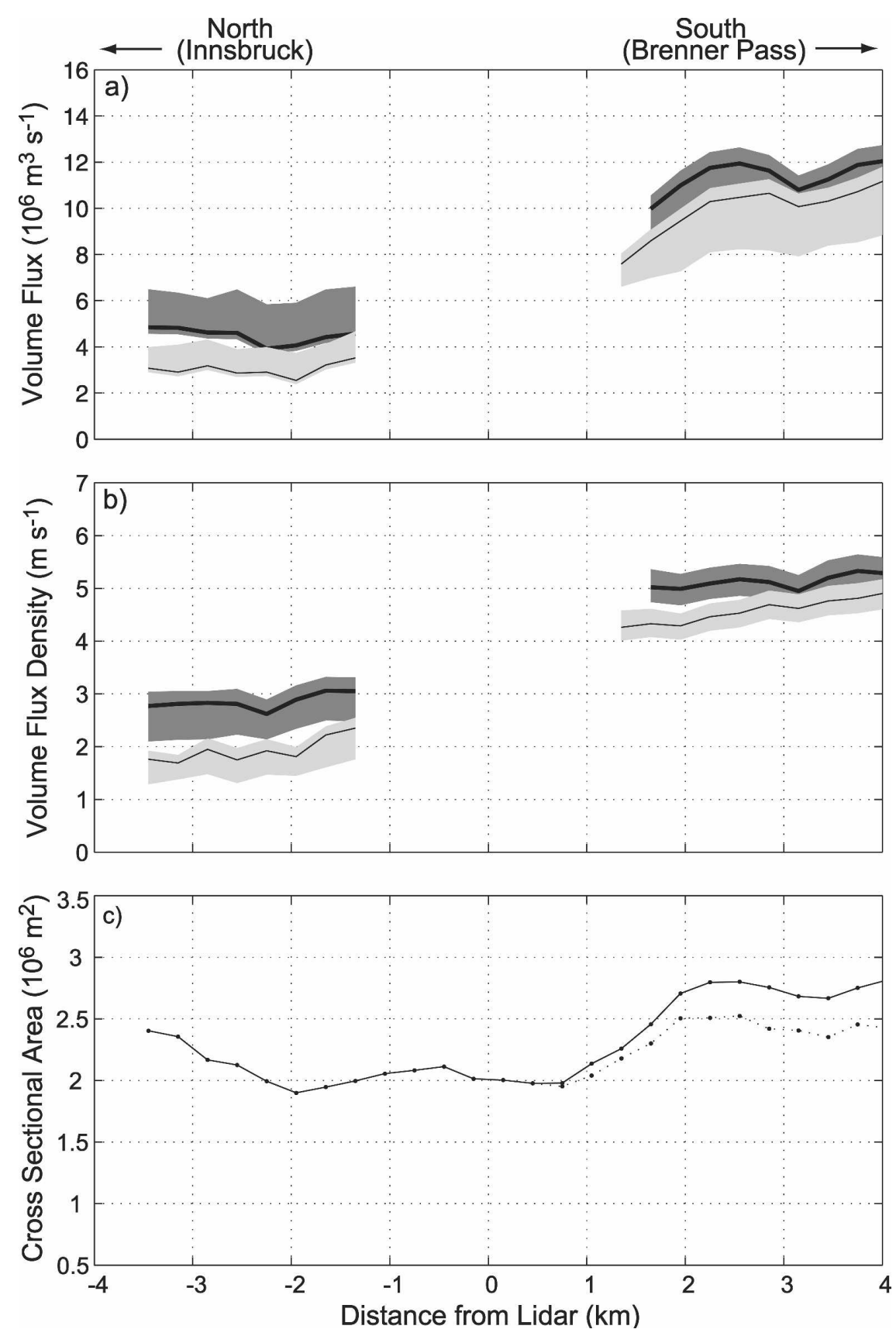

FIG. 11. (a) Along-valley volume flux and (b) volume flux density as a function of alongvalley distance for 17 Oct 1999 at 1353 UTC (heavy line) and 1425 UTC (thin line). Uncertainty estimates are represented by the shaded areas. (c) Cross-sectional area as a function of along-valley distance is shown. The dotted line represents the cross-sectional areas for modified cross sections. Up-valley direction is to the right.

surrounding ridgelines and thus was not laterally confined by valley sidewalls. However, estimations for an 800-m-deep flow layer (Table 3) show similar increases in the along-valley volume flux and volume flux density between two ranges gates located approximately $2 \mathrm{~km}$ north and south of the lidar site for 11 and 16 Octo- ber as found for 17 October. It may therefore be concluded that the along-valley volume flux divergence is not a function of ambient flow conditions. The subsidence rate based on the along-valley volume flux divergence for all three days varies between 0.38 and $0.62 \mathrm{~m} \mathrm{~s}^{-1}$. 
TABLE 3. Along-valley volume flux, volume flux density, and subsidence rate due to the along-valley volume flux divergence for an 800-m-deep flow layer at approximately $2 \mathrm{~km}$ north (RG7 DV) and $2 \mathrm{~km}$ south (RG7 UV) of the lidar site for 11, 16, and 17 Oct 1999.

\begin{tabular}{|c|c|c|c|c|c|c|}
\hline \multirow[b]{2}{*}{ Date } & \multirow[b]{2}{*}{$\begin{array}{l}\text { Time } \\
\text { (UTC) }\end{array}$} & \multicolumn{2}{|c|}{$\begin{array}{l}\text { Volume flux } \\
\left(10^{6} \mathrm{~m}^{3} \mathrm{~s}^{-1}\right)\end{array}$} & \multicolumn{2}{|c|}{$\begin{array}{l}\text { Flux density } \\
\qquad\left(\mathrm{m} \mathrm{s}^{-1}\right)\end{array}$} & \multirow[b]{2}{*}{$\begin{array}{l}\text { Subsidence } \\
\quad\left(\mathrm{m} \mathrm{s}^{-1}\right)\end{array}$} \\
\hline & & $\begin{array}{c}\text { RG7 } \\
\text { DV }\end{array}$ & $\begin{array}{c}\text { RG7 } \\
\text { UV }\end{array}$ & $\begin{array}{c}\text { RG7 } \\
\text { DV }\end{array}$ & $\begin{array}{c}\text { RG7 } \\
\text { UV }\end{array}$ & \\
\hline 11 Oct & 1217 & 4.2 & 13.7 & 2.9 & 6.1 & 0.62 \\
\hline \multirow[t]{8}{*}{16 Oct } & 1059 & 1.2 & 7.4 & 0.8 & 3.3 & 0.40 \\
\hline & 1133 & 3.3 & 8.3 & 2.3 & 3.8 & 0.32 \\
\hline & 1204 & 2.6 & 10.1 & 1.8 & 4.6 & 0.49 \\
\hline & 1225 & 3.4 & 9.3 & 2.4 & 4.5 & 0.38 \\
\hline & 1302 & 3.3 & 11.1 & 2.3 & 5.0 & 0.51 \\
\hline & 1405 & 3.4 & 12.0 & 2.4 & 5.4 & 0.56 \\
\hline & 1450 & 3.4 & 11.5 & 2.4 & 5.2 & 0.53 \\
\hline & 1516 & 4.3 & 11.4 & 3.1 & 5.1 & 0.46 \\
\hline \multirow[t]{2}{*}{17 Oct } & 1353 & 4.1 & 11.0 & 2.9 & 5.0 & 0.45 \\
\hline & 1425 & 2.5 & 9.4 & 1.8 & 4.3 & 0.45 \\
\hline
\end{tabular}

As discussed above, the volume flux analysis for 17 October shows a continued increase in the along-valley volume flux density downstream of the valley constriction. Although the valley flow on 16 October clearly intensifies through the valley constriction, an acceleration of the valley flow downstream of the constriction is not evident (see Fig. 5). The reason for the different flow behavior is not yet understood. The presence of a temperature inversion on 17 October suggests that the acceleration downstream of the constriction may be explained using hydraulic theory. To determine if the flow up valley from the lidar site reached supercritical condition, we calculated the Froude number following Zängl et al. (2001) using the formula $U(h g \Delta \theta / \bar{\theta})^{-1 / 2}$, where $U$ is the mean wind speed across the flow layer, $h$ is the depth of the flow, $\bar{\theta}$ is the average potential temperature of the flow layer, and $\Delta \theta$ is the jump in potential temperature across the inversion. Using values of $U=6 \mathrm{~m} \mathrm{~s}^{-1}$ and $h=800 \mathrm{~m}$ based on lidar observations, and $\Delta \theta=5.5 \mathrm{~K}$ and $\bar{\theta} \approx 285 \mathrm{~K}$ based on the 1200 UTC sounding at Innsbruck Airport, the Froude number is roughly 0.5 . Using more conservative values of $U=7 \mathrm{~m} \mathrm{~s}^{-1}, h=600 \mathrm{~m}$ and $\Delta \theta=3 \mathrm{~K}$, the Froude number increases to 0.9 , but still falls short of unity. This suggests that the continued acceleration of the flow downstream of the constriction is likely not due to hydraulic processes.

\section{Discussion}

Although divergence of the along-valley mass/ volume flux is logical for nighttime valley flows, it is counterintuitive for the daytime case since flow is generally removed from the valley atmosphere through slope and tributary flows. Nevertheless, as in this study, along-valley volume flux divergence for daytime valley flows has been inferred for two other valleys, the Inn Valley (Freytag 1987) and the Kali Gandaki Valley (Egger et al. 2000). It can be argued that, in all three valleys, an increase in wind speed occurs in valley segments where there is a decrease in the cross-sectional area. Increases in the along-valley mass/volume flux in those valleys, however, suggest that the lateral constrictions in the valley sidewalls cannot entirely explain the increases in wind speed.

A number of explanations have been suggested for the observed increase in wind speed in the Kali Gandaki Valley and Inn Valley. For the Kali Gandaki Valley, model simulations by Zängl et al. (2001) first pointed to hydraulic theory as a way to explain the increase in wind speed. Subsequent field measurements (Egger et al. 2002), however, have shown that a capping temperature inversion-a necessary requirement for hydraulic theory - is not present at all times, and hence a satisfactory explanation for the flow mechanism in the Kali Gandaki Valley is still outstanding (Egger et al. 2002). For the Inn Valley, Freytag $(1987,1988)$ postulated that the increase in mass flux was due to subsidence over the main valley, which quasi-locally compensated for flow into tributary valleys. In an earlier study, Vergeiner (1983) observed an increase in the daytime surface wind speed and pressure gradient along the same narrow segment in the Inn Valley [see Fig. 14 of Vergeiner and Dreiseitl (1987)], but used conservation of the along-valley mass flux to explain the increase in wind speed. More recently, a numerical study by Zängl (2004) suggested that flow enters the Inn Valley through tributaries that link the Inn Valley with the Alpine foreland and thus contributes to the increase in mass flux in the Inn Valley.

Work by Vergeiner and Dreiseitl (1987) points to a fourth plausible explanation for the increase in wind speed in the Inn Valley, which has not yet received attention in the literature. Table 2 of Vergeiner and Dreiseitl (1987) lists the diurnal ranges (between 0600 and 1500 UTC) of vertically averaged temperature under fair-weather conditions for a number of stations along the Inn Valley and on the adjacent plain. The monotonic, along-valley increase in the diurnal heating rate leads to an along-valley temperature gradient, which in turn produces an along-valley pressure gradient. The along-valley increase in the diurnal heating rate is attributed to the general decrease in valley volume along the length of the Inn Valley (Vergeiner and Dreiseitl 1987). The same table, however, also shows 
that the rate of change of the diurnal heating rate is not constant along the valley, but varies between the valley segments. In particular, the largest rate of change of the diurnal heating rate occurs in the same narrow valley segment (Rattenberg-Schwaz) in which the increase in wind speed has been observed in the other studies (Vergeiner 1983; Freytag 1987, 1988). It thus appears plausible that the acceleration of the flow along the Inn Valley is due to a local increase in the along-valley pressure gradient which is caused by a higher heating rate along the narrow portion of the valley. In addition to the volume effect, the heating rate of the valley atmosphere is also likely influenced by flow dynamics.

With the lack of thermodynamic data in the Wipp Valley, it is not possible to determine if the along-valley acceleration of the valley flow is due to differences in the heating rate of the valley atmosphere. It is possible, however, that processes similar to those proposed for the Inn Valley also occur in the Wipp Valley. The effects of topography and flow dynamics on the heating rates of the atmosphere in the Wipp Valley will be explored in a future modeling study.

\section{Summary}

In this study, highly spatially resolved Doppler lidar observations of thermally driven valley flows are presented for three days. The observations show that, on each of the days-despite somewhat different ambient flow conditions-the along-valley wind speed increased with distance in the up-valley direction through a narrow section of the valley. In addition, the observations suggest that the vertical wind structure changed along the valley from a relatively flat profile to a Prandtl-type profile. Volume flux analyses show that the alongvalley volume flux diverged in the valley segment under investigation. This implies that the along-valley increase in wind speed cannot be explained by the lateral constrictions of valley sidewalls. On days when the morning transition period was captured by the Doppler lidar, the transition from down-valley to up-valley flow aloft occurred more quickly south of the lidar site than north of the lidar site.

Since the along-valley volume flux divergence appears to be a persistent flow feature in this valley segment, it is hypothesized that the change in the geometry of the valley induces a localized change in the heating rate of the valley atmosphere and hence also a localized change in the horizontal pressure gradient, which in turn causes the flow to accelerate. The effects of topography as well as dynamic processes on the spatial valley flow structure will be examined in more detail with the help of numerical modeling in a future contribution.
Acknowledgments. The authors thank Georg Mayr for his organizational efforts of the MAP field campaign in the Brenner Pass area; Stephan Mobbs for providing surface measurements; and Lisa Darby, Janet Intrieri, Richard Marchbanks, and Jim Howell for their assistance in obtaining the lidar data. The authors also thank the anonymous reviewers as well as Lisa Darby and Dr. Jian-Wen Bao for helpful comments on the manuscript. This research was supported through NSERC and CFCAS grants to D. Steyn and through NOAA/ETL partial traveling funds to M. Rucker; R. Banta was supported through the Environmental Research Laboratories, Office of Atmospheric Research, Special MAP Project Funding.

\section{REFERENCES}

Atkinson, B. W., 1981: Meso-scale Atmospheric Circulations. Academic Press, 495 pp.

Banta, R. M., 1984: Daytime boundary-layer evolution over mountainous terrain. Part I: Observations of the dry circulations. Mon. Wea. Rev., 112, 340-356.

_ , and W. R. Cotton, 1981: An analysis of the structure of local wind systems in a broad mountain basin. J. Appl. Meteor., 20, 1255-1266.

— L. D. Olivier, and D. H. Levinson, 1993: Evolution of the Monterey Bay sea-breeze layer as observed by pulsed Doppler lidar. J. Atmos. Sci., 50, 3959-3982.

$\longrightarrow,-$ W. D. Neff, D. H. Levinson, and D. Ruffieux, 1995: Influence of canyon-induced flows on flow and dispersion over adjacent plains. Theor. Appl. Climatol., 52, 27-42.

— L. S. Darby, P. Kaufmann, D. H. Levinson, and C.-J. Zhu, 1999: Wind-flow patterns in the Grand Canyon as revealed by Doppler lidar. J. Appl. Meteor., 38, 1069-1083.

, — J. D. Fast, J. O. Pinto, C. D. Whiteman, W. J. Shaw, and B. W. Orr, 2004: Nocturnal low-level jet in a mountain basin complex. Part I: Evolution and effects on local flows. $J$. Appl. Meteor., 43, 1348-1365.

Bougeault, P., and Coauthors, 2001: The MAP special observing period. Bull. Amer. Meteor. Soc., 82, 433-462.

Brehm, M., and C. Freytag, 1982: Erosion of the night-time thermal circulation in an alpine valley. Arch. Meteor. Geophys. Bioklimatol., 31B, 331-352.

Buettner, K. J. K., and N. Thyer, 1965: Valley winds in the Mount Rainier area. Arch. Meteor. Geophys. Bioklimatol., 14B, 125147.

Dreiseitl, E., H. Feichter, H. Pichler, R. Steinacker, and I. Vergeiner, 1980: Wind regimes near the fork of two alpine valleys (in German). Arch. Meteor. Geophys. Bioklimatol., 28B, 257275.

Durran, D. R., T. Maric, R. M. Banta, L. S. Darby, and R. M. Hardesty, 2003: A comparison of ground-based Doppler lidar and airborne in situ wind observations above complex terrain. Quart. J. Roy. Meteor. Soc., 129, 693-713.

Egger, J., S. Bajrachaya, U. Egger, R. Heinrich, J. Reuder, P. Shayka, H. Wendt, and V. Wirth, 2000: Diurnal winds in the Himalayan Kali Gandaki Valley. Part I: Observations. Mon. Wea. Rev., 128, 1106-1122.

— 
Gandaki Valley. Part III: Remotely piloted aircraft soundings. Mon. Wea. Rev., 130, 2042-2058.

Flamant, C., and Coauthors, 2002: Gap flow in an Alpine valley during a shallow south föhn event: Observations, numerical simulations and hydraulic analogue. Quart. J. Roy. Meteor. Soc., 128, 1173-1210.

Freytag, C., 1987: Results from the MERKUR experiment: Mass budget and vertical motions in a large valley during mountain and valley wind. Meteor. Atmos. Phys., 37, 129-140.

- 1988: Atmospheric boundary layer in an Alpine valley during mountain and valley flows (in German). Wiss. mitt. nr. 60, Meteorologisches Institut, Universität München, 197 pp.

Gohm, A., G. Zängl, and G. J. Mayr, 2004: South Foehn in the Wipp Valley on 24 October 1999 (MAP IOP 10): Verification of high-resolution numerical simulations with observations. Mon. Wea. Rev., 132, 78-102.

Henne, S., and Coauthors, 2004: Quantification of topographic venting of boundary layer air to the free troposphere. Atmos. Chem. Phys., 4, 497-509.

Hennemuth, B., 1987: Heating of a small Alpine valley. Meteor. Atmos. Phys., 36, 287-296.

- , and H. Schmidt, 1985: Wind phenomena in the Dischma valley during DISKUS. Arch. Meteor. Geophys. Bioklimatol., 35B, 361-387.

King, C. W., 1989: Representativeness of single vertical wind profiles for determining volume flux in valleys. J. Appl. Meteor., 28, 463-466.

Mayr, G. J., and Coauthors, 2004: Gap flow measurements during the Mesoscale Alpine Programme. Meteor. Atmos. Phys., 86, 99-119.

McKee, T. B., and R. D. O'Neal, 1989: The role of valley geometry and energy budget in the formation of nocturnal valley winds. J. Appl. Meteor., 28, 445-456.

Post, M. J., and W. D. Neff, 1986: Doppler lidar measurements of winds in a narrow mountain valley. Bull. Amer. Meteor. Soc., 67, 274-281.

— Appl. Opt., 29, 4145-4158.

Prandtl, L., 1942: Führer durch die Ströhmungslehre (Guide to Fluid Mechanics). Vieweg und Sohn, 382 pp.

Prévôt, A. S. H., M. Furger, B. Neininger, L. Poggio, J. Dommen, and W. Graber, 1998: Mesolcina Valley=Highly efficient air pump for vertical transport. Proc. Eighth Conf. on Mountain Meteorology, Flagstaff, AZ, Amer. Meteor. Soc., 401-403.

Rao, P. K., 1968: An investigation of the valley-plain wind circulation in the valleys of Vermont. Ph.D. dissertation, New York University, $110 \mathrm{pp}$.

Reiter, R., H. Müller, R. Sladkovic, and K. Munzert, 1983: Aerologische Untersuchungen der tagesperiodischen Gebirgswinde unter besonderer Berücksichtigung des Windfeldes im Talquerschnitt (Aerological investigation of periodic moun- tain winds with special consideration of cross-sectional wind fields). Meteor. Rundsch., 36, 225-242.

_ _ _ and _ 1984: Die vertikale Windstruktur beim MERKUR-Schwerpunkt "Tagesperiodische Windsysteme" aufgrund von aerologischen Messungen im Inntal und im Rosenheimer Becken (Vertical flow structure of diurnal wind systems during MERKUR, based on aerological observations in the Inn Valley and in the Rosenheim Basin). Arch. Meteor. Geophys. Bioklimatol., 33B, 359-372.

Rucker, M., 2003: Observational and numerical study of daytime flows in an alpine valley. Ph.D. dissertation, University of British Columbia, 164 pp.

Steinacker, R., 1984: Area-height distribution of a valley and its relation to the valley wind. Beitr. Phys. Atmos., 57, 64-71.

Vergeiner, I., 1983: Dynamics of alpine wind systems (in German). Forschungsprojekt 3556 des Fonds zur Förderung der wissenschaflichen Forschung, Institut für Meteorologie und Geophysik, Innsbruck, Austria, 129 pp.

—, and E. Dreiseitl, 1987: Valley winds and slope winds-Observations and elementary thoughts. Meteor. Atmos. Phys., 36, 264-286.

Wagner, A., 1932: Daily air pressure and temperature changes in the free atmosphere and in mountain valleys (in German). Gerlands Beitr. Geophys., 37, 315-344.

Weigel, A. P., and M. W. Rotach, 2004: Flow structure and turbulence characteristics of the daytime atmosphere in a steep and narrow Alpine valley. Quart. J. Roy. Meteor. Soc., 130, 2605-2627.

Weissmann, M. D., G. J. Mayr, R. M. Banta, and A. Gohm, 2004: Observations of the temporal evolution and spatial structure of the gap flow in the Wipp Valley on 2 and 3 October 1999. Mon. Wea. Rev., 132, 2684-2697.

Whiteman, C. D., 1982: Breakup of temperature inversions in deep mountain valleys: Part I. Observations. J. Appl. Meteor., 21, 270-289.

- 1990: Observations of thermally developed wind systems in mountainous terrain. Atmospheric Processes over Complex Terrain, Meteor. Monogr., No. 45, Amer. Meteor. Soc., 5-42. , and E. Dreiseitl, 1984: Alpine meteorology: Translations of classic contributions by A. Wagner, E. Ekhart, and F. Defant. Pacific Northwest Laboratory Tech. Rep. PNL-5141/ ASCOT-84-3, 47-72.

_ and J. C. Doran, 1993: The relationship between overlying synoptic-scale flows and winds within a valley. J. Appl. Meteor., 32, 1669-1682.

Zängl, G., 2004: A reexamination of the valley wind system in the Alpine Inn Valley with numerical simulations. Meteor. Atmos. Phys., 87, 241-256.

—, J. Egger, and V. Wirth, 2001: Diurnal winds in the Himalayan Kali Gandaki Valley. Part II: Modeling. Mon. Wea. Rev., 129, 1062-1080. 